\title{
Chapter 8 \\ Covering the Gap for an Effective Energy and Environmental Design of Green Roofs: Contributions from Experimental and Modelling Researches
}

\section{Laura Cirrincione and Giorgia Peri}

\begin{abstract}
Green roofs are components of the building envelope that have become increasingly popular in urban contexts because other than providing numerous environmental benefits they are also capable of reducing building energy consumption, especially in summer. However, despite all these advantages, green roofs are still affected by some limitations. Specifically, there are some gaps affecting the energy modelling consisting in the absence of a proper database, information (growth stage, leaf area index, and coverage ratio) relative to the different green roof plant species, which technicians could use in case of lack of actual field data to perform energy analysis of buildings equipped with green roofs. These gaps concern also environmental and economic assessments of such technology. In fact, the currently available green roof LCA and LCC studies seem to underestimate the role of the substrate on the overall environmental impact and the role of the disposal phase on the life cycle cost of the green roof. In this chapter, all these aspects are addressed, and contributions to their solution, which arose from both experimental and modelling research, carried out by the authors are presented.
\end{abstract}

Keywords Green roofs · LCA · Radiative heat exchanges · Energy analysis · Environmental analysis

\footnotetext{
L. Cirrincione $(\bowtie)$

Department of Engineering, University of Palermo, Palermo, Italy

ERIN - Environmental Research \& Innovation Department, Luxembourg Institute of Science and Technology (LIST), Belvaux, Luxembourg

e-mail: laura.cirrincione@unipa.it

G. Peri

Department of Engineering, University of Palermo, Palermo, Italy

e-mail: giorgia.peri@unipa.it
} 


\subsection{Introduction}

Green roofs represent an increasingly important building-passive component in urban contexts due to the many benefits that can be attributed to them. Green roofs allow indeed to reduce the air pollution (Abhijith et al., 2017; Zhang et al., 2015), mitigate noise (Liu \& Hornikx, 2018; Van Renterghem, 2018), improve the management of runoff water (Soulis, Ntoulas, Nektarios, \& Kargas, 2017; Vijayaraghavan, Reddy, \& Yun, 2019), increase the urban biodiversity (Francis \& Jensen, 2017; Köhler \& Ksiazek-Mikenas, 2018), and ease the Urban Heat Island (UHI) effects (Bevilacqua, Mazzeo, Bruno, \& Arcuri, 2017; Peri, Rizzo, Scaccianoce, \& Sorrentino, 2013; Solcerova, van de Ven, Wang, Rijsdijk, \& van de Giesen, 2017; Yang et al., 2018). As regards this latter, a possible reduction of the average ambient temperature ranging between 0.3 and $3 \mathrm{~K}$ has been indicated for vegetated roofs, when deployed on a city scale, thanks to the evapotranspiration effect (Santamouris, 2014). A review of all the advantages provided by green roofs is presented in (Shafique, Kim, \& Rafiq, 2018).

Apart from the above-cited several environmental benefits, vegetated roofs have also become increasingly appealing as a technological option due to their capacity in decreasing the buildings' climatization energy consumption and, at the same time, improving the indoor thermal comfort levels (Cirrincione et al., 2020). Their suitability in improving the energy performance of buildings equipped with them has largely been addressed in literature over the recent years. Based on a literature review we conducted previously (La Gennusa et al., 2019a, 2019b), it arises that

1. there is a wide agreement among scientists on the fact that, during the summer period, the presence of green roofs provides a thermal protection for the building (Niachou,Papakonstantinou, Santamouris, Tsangrassoulis, \&Mihalakakou, 2001);

2 . on the contrary, the performance of vegetated roofs in winter is somewhat a controversial issue; in fact, green roofs mostly reduce the total heating load (Silva, Gomes, \& Silva, 2016), but, in some cases, they do not produce any advantage or even cause slightly adverse conditions (Jaffal, Ouldboukhitine, \& Belarbi, 2012; Santamouris et al., 2007);

3 . vegetated roofs have mostly a positive impact on the total energy consumption of buildings (Jaffal et al., 2012; Niachou et al., 2001; Santamouris et al., 2007) implying a net reduction of the total annual energy demand compared to traditional roofs.

The reasons of such behaviour can be traced in some characteristics of this type of roof that have an influence on green roof thermal and energy performance. Specifically, factors that contribute to reduce the energy demand for cooling purposes. Thus, the above-mentioned positive effect can be summarized as follows:

1. Direct shading of the roof by the vegetation

2. Cooling of the air surrounding the roof due to the evapotranspiration process

3. Higher value of the roof albedo (typical values range from 0.7 to 0.85 [Saadatian et al., 2013]). 
While items that contribute to reduce the energy demand for heating purposes can be summarized as follows:

1. Additional insulation layer provided by the technological system "green roof" added to the roof

2. Lower thermal convention on the external surface due to the presence of the vegetation.

Nonetheless, some circumstances that may increase the heat losses, rather than decreasing them, may occur. Among these, the climatic conditions and especially the precipitation regime of the site where the green roof is located, which have an influence on the effect provided by green roofs in winter, and particularly their additional insulation level which modifies the soil humidity content and in turn the soil thermal conductivity.

Despite all the so far mentioned numerous important benefits related to the use of green roofs as building envelope component, there are currently some modelling gaps increasing the time required for their design phases, on which improvements can be made; these gaps concern both environmental and economic aspects. Hereafter, we address the points mentioned above and list some contributions to their solution, particularly referred to extensive green roofs, that arose from both our experimental and modelling research.

\subsection{An Insight into the Energy Modelling of Green Roofs and on some of Its Currents Gaps}

As far as the modelling of green roofs is concerned, it should be noted that the high complexity characterizing the heat transfer occurring in a green roof, especially due to the presence of the vegetation and substrate, makes it complicated to implement a detailed model (Del Barrio, 1998). Therefore, it becomes necessary to assume simplifying hypotheses. Among these hypotheses, one is related to the behaviour of the canopy layer and it consists in approaching the vegetation layer through the socalled "big-leaf approach", which is typically used to assess the solar absorption attributable to the green roof canopies (De Pury \& Farquhar, 1997; Monteith, 1965).

In order to properly model the energy performance of buildings provided with green roofs (considered as passive components), some reliable, yet simplified, mathematical procedures have been implemented and are available in literature. An extensive review of them is well presented in (Quezada-García, Espinosa-Paredes, Polo-Labarrios, Espinosa-Martínez, \& Escobedo-Izquierdo, 2020). Among these, the one developed by Sailor (Sailor, 2008) has also been implemented in one of the most widely used building energy simulation software, i.e., EnergyPlus (EnergyPlus). Table 8.1 lists the typical input parameters requested by this simulation tool for calculating the different heat transfer components of the energy balance of a green roof and thus its contribution to the energy consumption of building. As it can be observed, green-roof-related input data are essentially related to vegetation and soil layers. 
Table 8.1 Main input parameters required by EnergyPlus to calculate the effect of a green roof on the energy consumption of a building equipped with it (Peri, Rizzo, Scaccianoce, La Gennusa, \& Jones, 2016)

\begin{tabular}{|c|c|c|c|}
\hline $\begin{array}{l}\text { Green } \\
\text { roof's } \\
\text { layer }\end{array}$ & Parameter & $\begin{array}{l}\text { Parameter's } \\
\text { unit }\end{array}$ & Parameter's description \\
\hline \multirow[t]{6}{*}{ Canopy } & Leaf reflectance & $(-)$ & $\begin{array}{l}\text { It measures the percentage of incident solar } \\
\text { radiation reflected by the leaf. }\end{array}$ \\
\hline & Leaf emissivity & $(-)$ & $\begin{array}{l}\text { It is the ratio between the thermal radiation } \\
\text { emitted by the leaf and that emitted by a } \\
\text { black body at the same temperature. }\end{array}$ \\
\hline & Leaf area index (LAI) & $(-)$ & It measures the vegetation density. \\
\hline & Height of the plants & (m) & $\begin{array}{l}\text { It represents the average height of } \\
\text { vegetable species. }\end{array}$ \\
\hline & $\begin{array}{l}\text { Minimum stomatal } \\
\text { resistance }\end{array}$ & $(\mathrm{s} / \mathrm{m})$ & $\begin{array}{l}\text { It measures the resistance offered to vapour } \\
\text { diffusion from the pores on the plant } \\
\text { leaves. }\end{array}$ \\
\hline & Roughness class & $\begin{array}{l}\text { Smooth/ } \\
\text { medium/ } \\
\text { rough }\end{array}$ & $\begin{array}{l}\text { It gives an indication on the surface texture } \\
\text { of the leaves. }\end{array}$ \\
\hline \multirow[t]{9}{*}{ Substrate } & Soil thickness & (m) & It is a geometrical property of the soil. \\
\hline & $\begin{array}{l}\text { Conductivity of dry } \\
\text { soil }\end{array}$ & $(\mathrm{W} /(\mathrm{mK}))$ & $\begin{array}{l}\text { It indicates the substrate's capability to } \\
\text { transfer heat by conduction. }\end{array}$ \\
\hline & Density of dry soil & $\left(\mathrm{kg} / \mathrm{m}^{3}\right)$ & $\begin{array}{l}\text { It indicates the mass of dry soil that } \\
\text { occupies a unitary volume. }\end{array}$ \\
\hline & Specific heat dry soil & $(\mathrm{J} /(\mathrm{kg} \mathrm{K}))$ & $\begin{array}{l}\text { It indicates the amount of heat needed to } \\
\text { provide to the unitary mass of dry soil to } \\
\text { increase its temperature of } 1 \text { degree. }\end{array}$ \\
\hline & Thermal absorptance & $(-)$ & \multirow{3}{*}{$\begin{array}{l}\text { It measures the percentage of radiation } \\
\text { absorbed by the soil in the infrared, } \\
\text { ultraviolet, and visible range of the } \\
\text { electromagnetic spectrum. }\end{array}$} \\
\hline & Solar absorptance & $(-)$ & \\
\hline & Visible absorptance & $(-)$ & \\
\hline & $\begin{array}{l}\text { Saturation volumetric } \\
\text { moisture content of } \\
\text { the soil layer }\end{array}$ & $(-)$ & $\begin{array}{l}\text { It represents the maximum volumetric } \\
\text { water content that the substrate can store. }\end{array}$ \\
\hline & $\begin{array}{l}\text { Residual volumetric } \\
\text { moisture content of } \\
\text { the soil layer }\end{array}$ & $(-)$ & $\begin{array}{l}\text { It indicates the minimum possible } \\
\text { volumetric water content that a soil can } \\
\text { undertake after a drying process. }\end{array}$ \\
\hline
\end{tabular}

\subsubsection{Radiative Inter-Canopies Heat Exchanges: The Lack of a Proper Database of Pertinent Physical Parameters}

Relatively to the energy issues, one of the biggest limitations is represented by the lack of knowledge of the mechanisms and physical parameters that govern radiative exchanges between the plants and the external environment and between the plant essences themselves ("intercanopies heat exchanges").

Based on a literature review carried out by the authors, aimed at investigating the availability and typology of some parameters related to vegetation and soil (i.e., 
experimental or analytical data, obtained both from experimental applications and theoretical data on plant canopies, plant species, and growth stage which the available data are referred to) (Peri et al., 2016), it has emerged the absence of a proper database containing information (growth stage, leaf area index, and coverage ratio) for different green roof plant species, which technicians could utilize in the eventuality of a lack of specific field data. This circumstance has been found especially in the case of shortwave radiation exchange inside the green roof canopy layer, which is a component of the green roofs' energy balance that, as demonstrated by Feng et al. in their work (Feng, Meng, \& Zhang, 2010), plays an important role in the green roofs' energy balance. More specifically, it has been noticed that the current database containing the required data parameters to model this component of the radiative exchanges occurring within green roofs' canopies has some inherent limitations:

- is so far quite limited because it is referred only to a few plant species;

- almost all investigated parameters range of values are usually rather large (e.g., LAI values found range from 1 to 5), which could make even more challenging the choice of the values most appropriate for each of the models;

- (existing databases) do not fit this kind of roof peculiarities, represented by the fact that such component consists of living elements (i.e., vegetation) that grow and/or decay with time, modifying important parameters involved in the modelling of the green roof, such as the (LAI) and the coverage ratio (La Gennusa, Peri, Scaccianoce, Sorrentino, \& Aprile, 2018; Peri et al., 2016; Santamouris et al., 2007). Changes in such variables, which obviously influence the building energy savings related to green roofs (Silva et al., 2016; Zinzi \& Agnoli, 2012), have been found to be frequently simplified instead, meaning that the available values in literature concern specific growth levels of specific plant species.

Therefore, in our opinion, the absence of a proper database appears of no negligible importance because a technician, who is tasked to assess the green roof impact on the energy consumption of a building equipped with it, might be forced to refer to common values, which do not represent the specific vegetated implantation; this circumstance may imply a simulation scenario not comparable with the actual one, that might lead to an inaccurate assessment of the buildings' thermal loads (heating and cooling).

In this respect, we have performed an evaluation of the buildings' energy estimation errors that might occur when using generic values for the green roofs' vegetation parameters. The outcomes of such estimation were compared to the results obtained from experimental data, deriving from a monitoring campaign (conducted by the authors) that is described in the following (paragraph 1.2).

In detail, the building yearly energy needs, both as summation of heating and cooling then separately, have been calculated, hypothesizing four different scenarios relative to the vegetation parameters to give as input to the utilized software (DesignBuilder@). In particular, the four considered parameters' set of values were the following:

- Field monitored data

- Fixed minimum values

- Maximum values

- Average values. 
Table 8.2 Potential errors due to the use generic vegetation data (Peri et al., 2016)

\begin{tabular}{l|l|l|l}
\hline \multirow{2}{*}{$\begin{array}{l}\text { Set of data assigned to the vegetation } \\
\text { parameters }\end{array}$} & \multicolumn{3}{|l}{ Ranges of errors potentially occurring } \\
\cline { 2 - 4 } & Cooling & Heating & $\begin{array}{l}\text { Annual } \\
\text { (heating + cooling) }\end{array}$ \\
\hline Minimum values & $\begin{array}{l}10 \% \text { and } \\
24 \%,\end{array}$ & $\begin{array}{l}14 \% \text { and } \\
33 \%,\end{array}$ & $8 \%$ and 17\%, \\
\hline Maximum values & $\begin{array}{l}4 \% \text { and } \\
14 \%,\end{array}$ & $\begin{array}{l}12 \% \text { and } \\
45 \%,\end{array}$ & $2 \%$ and $10 \%$ \\
\hline Average values & $1 \%$ and $9 \%$ & $\begin{array}{l}7 \% \text { and } \\
19 \% .\end{array}$ & $1.5 \%$ and $7 \%$ \\
\hline
\end{tabular}

The simulations' outcomes, listed in Table 8.2, put in light the need of improving the database with data specific for the typology of installed green roof, in order to render the building energy performance simulations more reliable. In fact, as it can be observed from the results, significant errors (up to $45 \%$ for heating) in the estimation of thermal loads might be related to the use of generic data.

\subsubsection{An Experimental-Side Contribution Towards More Reliable Energy Performance Simulations of Buildings with Green Roofs}

In order to contribute to populate the database of parameters related to the vegetation layer of extensive green roofs, required by the current calculation tools to assess the effect of a specific green roof on the energy consumption of a building, we decided to experimentally measure three important physical parameters governing the green roofs energy performance:

- Coverage ratio $\left(\sigma_{\mathrm{f}}\right)$

- Leaf area index (LAI)

- Foliage temperature (Tf).

The choice of these three parameters relies on the fact that the LAI provides information on the depth that the solar radiation has to go through before reaching the roof (indicating the level of its attenuation by the vegetation), while the coverage ratio, $\sigma_{f}$, identifies parts of the roofs directly hit by the solar radiation, which are then characterized by a different energy balance. We measured the growth-related parameters of these two plants according to technical protocols that refer to techniques widely diffused in the agrarian field. On the other hand, the foliage temperature, $\mathrm{T}_{\mathrm{f}}$, is clearly an important parameter of the vegetation's energy balance and, in turn, of the green roof's energy balance.

Six plant species were experimentally investigated with reference to different growth levels in the same lapse of time: Phyla nordiflora, Aptenia lancifolia, Mesembryanthenum barbatus, Gazania nivea, Gazania uniflora, and Sedum (see 


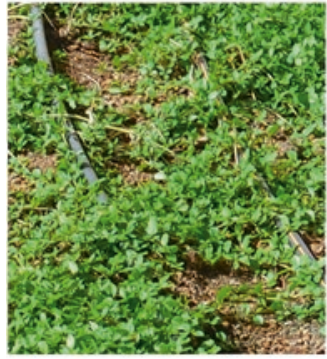

Phyla nordiflora

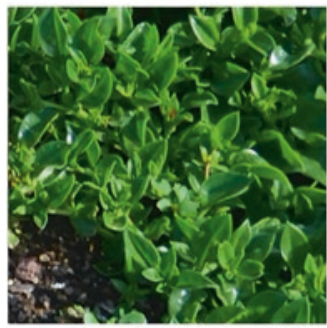

Aptenia lanceolin

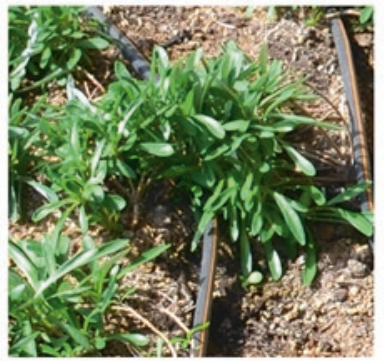

Gazania uniflora

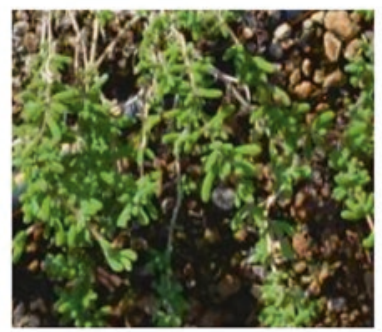

Mesembranthenum

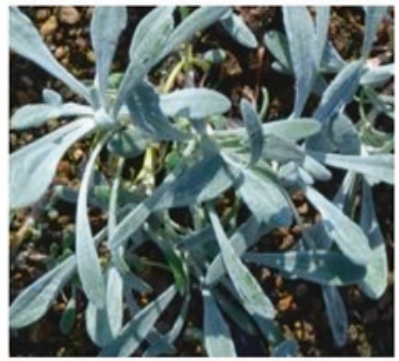

Gazania nivea

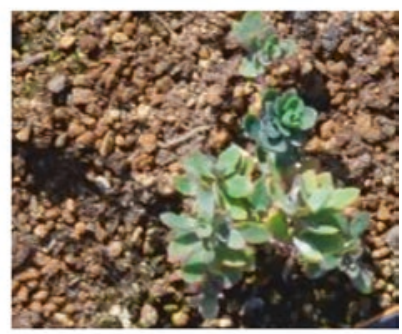

Sedum

Fig. 8.1 Plant species investigated in this study

Fig. 8.1). These vegetable species are planted into three plots of extensive green coverings, which are sited in the campus of the University of Palermo.

A simple optical procedure was used to obtain the coverage ratio (Walter, Burnham, Gilliam, \& Peterjohn, 2015), based on a pixel-counting procedure applied to some green roof squares digital pictures (to this aim, wooden squares were built ad hoc).

As regards the LAI measurements, a "destructive" procedure was used, consisting in leaf removal from plants with a subsequent leaves measurement by means of a leaf area meter.

Finally, the leaf temperatures, for every species and in both the upper and lower layers of the canopy, were taken using an infrared thermometer, in order to obtain a more representative value.

Proper ranges of the cited parameters have been found for each species. A more detailed description of the measurement campaign is presented in (Ferrante, La Gennusa, Peri, Rizzo, \& Scaccianoce, 2016).

As for the leaf temperature, its dependence on climatic parameters has been analysed as well and a correlation with some meteorological variables was estimated. In particular, the obtained distribution of experimental points for both the solar radiation and the air temperatures highlighted a linear equation as the best fitting curve (see Fig. 8.2). Graphs show that the correlation between the foliage temperature and the solar radiation is stronger compared to the one between the foliage temperature and the air temperature, as confirmed by the obtained autocorrelation 

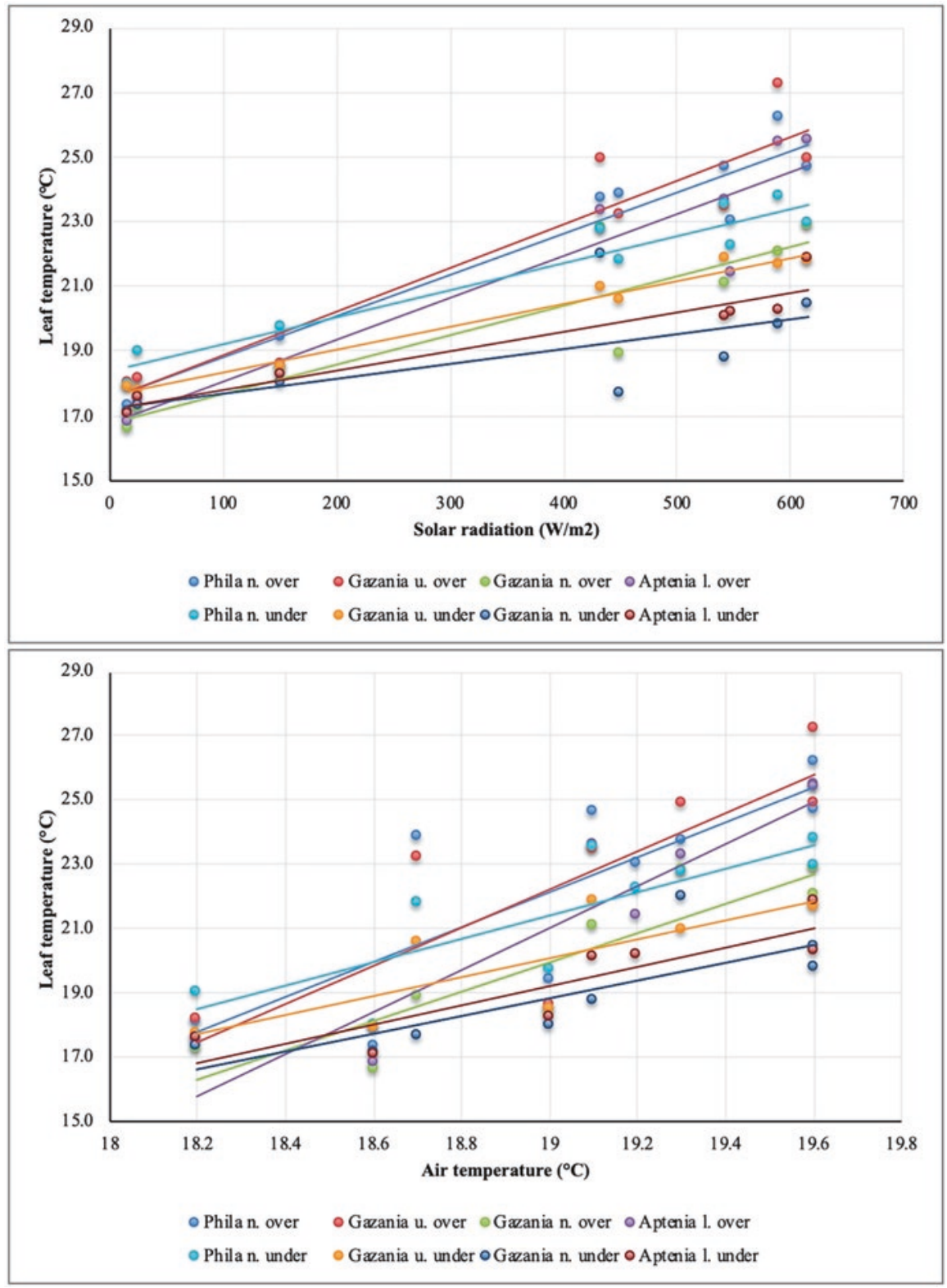

Fig. 8.2 Leaf temperature opposite solar radiation (up) and air temperature (down). (Adapted from Ferrante et al., 2016) 
coefficients values. This could have been expected, considering that leaves are more affected by the presence and/or absence of direct solar than by the air temperature, the response to the modifications of such parameter is in fact slower.

Clearly, in the aim of realizing a continuous and homogeneous green coverage to reduce the impact of solar radiation on the building roof, the thickness of the water storage layer also plays a role in the optimization of the components, other than the type of plant species, which is the most important factor. In this respect, we also conducted a monitoring campaign where the ceiling temperatures were measured in some rooms sited below an experimental green roof consisting of different plots, characterized both by distinct water storage thickness and plant species (Cirrincione et al., 2020). As expected, results pointed out a general propensity in achieving lower temperatures when the green coverage is taller and when the water storage layer is thicker; a ceiling temperature difference comprised between 1 and $3{ }^{\circ} \mathrm{C}$ was registered with respect to the plots presenting lower green coverages and thinner water storage layers.

\subsection{The Environmental Impact of a Green Roof}

Provided that, as mentioned in the Introduction section, vegetated roofs have become increasingly popular in urban contexts, in our opinion it seems quite relevant in understanding the actual environmental impact of such components, in order to understand whether their large-scale implementation might be a cause for concern.

\subsubsection{The Life Cycle of the Substrate: A Lack of LCA Studies on Green Roofs}

Although, in recent years, the growing interest in green roofs has led to a growth in the number studies regarding their overall performance, especially from a thermal point of view, and their effectiveness in different climatic contexts, (Bevilacqua, Bruno, \& Arcuri, 2020; Bevilacqua, Mazzeo, Bruno, \& Arcuri, 2016), specific environmental analyses regarding the substrate, currently available in literature, seem to be somehow lacking (Koura, Manneh, Belarbi, El Khoury, \& El Bachawati, 2017; Sailor \& Hagos, 2011; Zhao, Tabares-Velasco, Srebric, Komarneni, \& Berghage, 2014). Indeed, based on a literature review performed by the authors on green roof studies addressing environmental analyses of these components, it has emerged that the role of both the substrate and the disposal phase on the overall environmental impact of the green roof (Peri, Traverso, Finkbeiner, \& Rizzo, 2012a, 2012b) is currently underestimated. 
Two interesting studies about green roof performances and their comparison with standard roofs (Kosareo \& Ries, 2007; Saiz, Kennedy, Bass, \& Snail, 2006) analyse such building components by means of the well-known life cycle assessment (LCA) methodology. This is an internationally standardized procedure (ISO 14040 and ISO 14044) and essentially allows estimating the potential environmental impacts of given product/service though its entire life cycle on a given set of impact categories, such as, for instance, global warming, eutrophication, acidification, representing these latter well-known environmental issues. Nevertheless, both the analyses result not being fully exhaustive comprehensive: concerning the one performed in (Saiz et al., 2006), this observation is mostly linked to the disposal phase being completely overlooked, while regarding the study reported in (Kosareo \& Ries, 2007), it principally relates to the LCA lacking of a green roof significant element, i.e., the growing medium.

\subsubsection{An LCA Contribution Towards More Complete and Proper Analyses of the Whole Environmental Impact Exerted by a Green Roof During Its Whole Life Cycle}

In order to contribute in covering this gap and thus allowing a full and accurate utilization of the LCA methodology to achieve a more comprehensive description of the environmental performances of this building component, without the vegetation layer, a classical LCA methodology has been applied to a specific extensive green roof, built on the top of a Research Institute building sited in a small Sicilian town near Palermo (Italy). The entire life cycle of the substrate has also been included in the analysis, besides taking into account also the end of life of the green roof.

Green roof data related to the vegetation have not been considered in the analysis as it was not possible to obtain primary data (such as water and fertilizers) from the owners and/or handlers. Nevertheless, this is a typical limitation when one tries to carry out the LCA of a green roof (Kosareo \& Ries, 2007; Saiz et al., 2006).

A comprehensive description of the inventory phase and impact assessment phase is reported in (Peri et al., 2012a, 2012b).

The outcomes of the study (briefly summarized in Fig. 8.3) have underlined the importance of including the substrate in such kinds of analyses. More specifically, from our analysis it has emerged that the presence of the substrate should not be overlooked because the substrate, compared to the others elements, plays a significant role in the environmental impact of the end-of-life phase of green roofs. In fact, we have discovered that the substrate disposal in landfill (treatment hypothesized in the analysis) causes a dramatic "Aquatic Toxicity" potential.

It is also worth noting that the substrate requires the use of substances, such as fertilizers, that in the common environmental impact of buildings would not be normally considered. In other words, when performing an LCA of a building, whose 


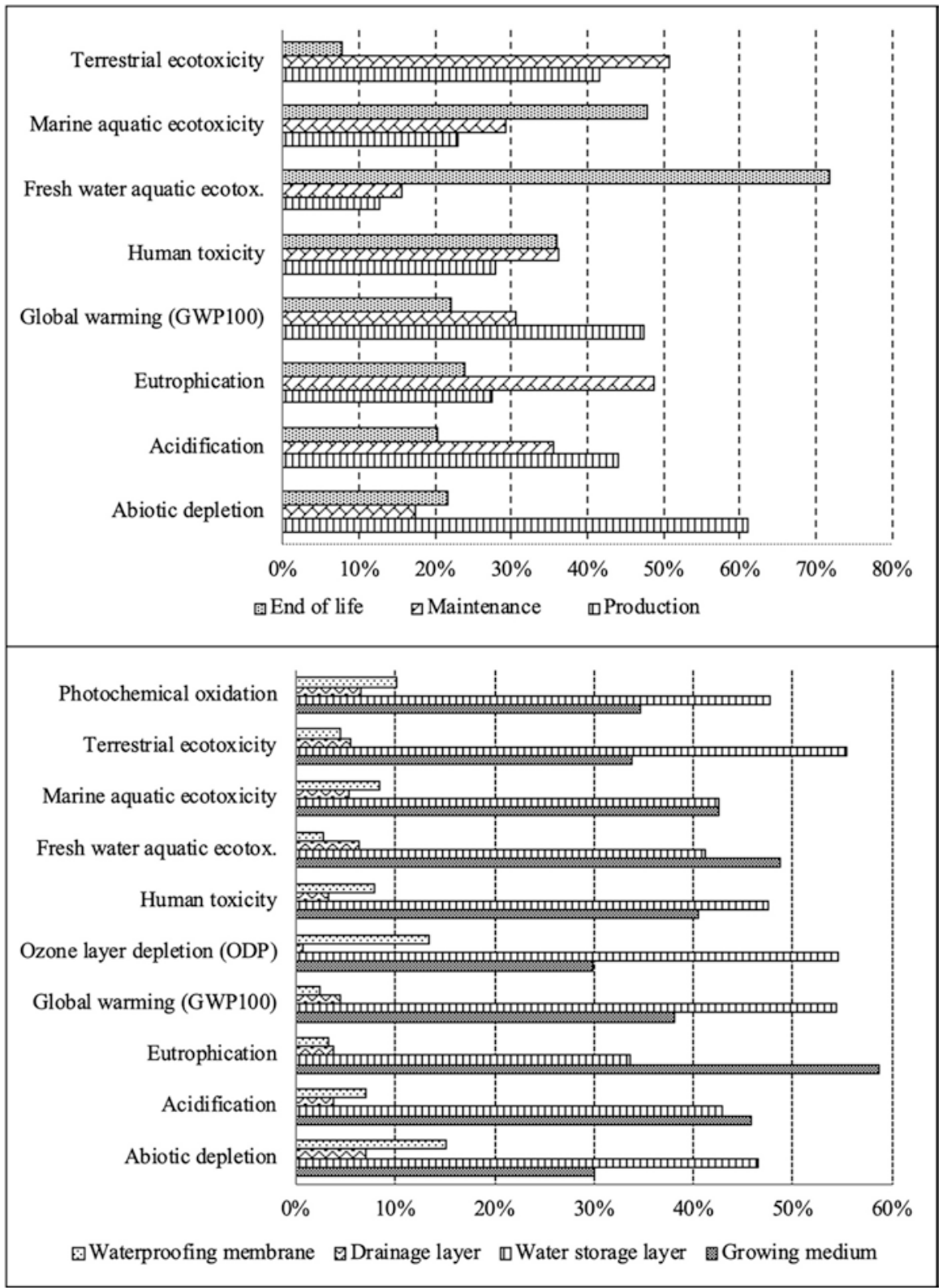

Fig. 8.3 Summarized characterization results of the LCA showing the weight of the substrate on the environmental impact of the green roof. (Adapted from Peri et al., 2012a, 2012b) 
roof is different from a green roof, the use of fertilizers is generally not contemplated because no cultivation soil is involved. In fact, the environmental impact of a building without a green roof is not commonly influenced by these substances. Considering the impact of fertilizers is important, because fertilizers cause, on the one hand, $\mathrm{NOx}$ and $\mathrm{N} 2 \mathrm{O}$ emissions during the use phase of the green roof and, on the other, their production process causes a high "Eutrophication and Terrestrial Toxicity" potential, as resulted in our study (Peri et al., 2012a, 2012b).

\subsection{The Economic Impact of a Green Roof}

As mentioned in the Introduction section, vegetated roofs have become increasingly common in urban contexts, especially for the many benefits they are capable of providing. In light of that, the knowledge of the actual cost of such technology from a life cycle perspective appears of no negligible importance too. In fact, obviously the feasibility of the adoption of the green roof as a building component depends on its life cycle cost. If this is too high, then this solution will not be economically viable and probably have to be discarded despite all the technical advantages it provides.

On the other hand, from the standpoint of people occupying a given building (tenant and/or owner) and thus paying the current costs of the electric energy, indeed reduced by the presence of the green roof, it might be useful to have at disposal simple but reliable criteria for assessing the economic feasibility of green roofs compared to other roofing options during the duty phase of the building.

\subsubsection{The Life Cycle of the Substrate: A Lack of LCA Studies on Green Roofs}

Although, over the last years, the economic evaluation of green roofs has gained more attention (Shafique et al., 2018; Shafique, Azam, Rafiq, Ateeq, \& Luo, 2020; Ulubeyli, Arslan, \& Kazaz, 2017), along with the environmental one, literature put in evidence how some components of the green roof life cycle cost analysis are often not taken into consideration. Specifically, the role of the disposal phase seems to be underestimated and/or lacking (Peri et al., 2012a, 2012b).

\subsubsection{An LCC Contribution Towards More Complete Analyses of All Life Cycle Cost of a Green Roof}

In order to contribute to the overcoming of this gap, we applied the Life Cycle Costing (LCC) methodology suggested by D. G. Woodward (Woodward, 1997) (that seems to be one of the most utilized and generalizable) to a real extensive green roof, by also extending it to the disposal phase, which was missing in previous 
Table 8.3 Cost components of the analysed green roof life cycle

\begin{tabular}{l|l|l|l}
\hline Cost components & $\begin{array}{l}\text { Total green } \\
\text { roof }[€]\end{array}$ & Functional unit $1 \mathrm{~m}^{2}[€]$ & $\begin{array}{l}{[\%]} \\
\text { incidence }\end{array}$ \\
\hline Initial investment cost & 6154 & $\begin{array}{l}75 \text { (for purchase of materials and } \\
\text { installation) }\end{array}$ & $36 \%$ \\
\hline $\begin{array}{l}\text { Maintenance cost } \\
\text { hypothesizing a life span of } \\
\text { 40 years }\end{array}$ & 10,100 & $\begin{array}{l}123 \text { (for adding substrate and } \\
\text { inspection to remove infesting and } \\
\text { fertilizing) }\end{array}$ & $60 \%$ \\
\hline $\begin{array}{l}\text { End of life cost for the } \\
\text { hypothesized scenario }\end{array}$ & 784 & 9 (landfill and incineration) & $4 \%$ \\
\hline The total life cycle cost & 17,000 & 207 & $100 \%$ \\
\hline
\end{tabular}

LCC and Benefit-Cost Analyses (BCA) studies. This case study (Peri et al., 2012a, $2012 \mathrm{~b}$ ) also allowed to perform a complete and proper application of the LCC methodology to achieve an economic evaluation of this component, at least for the abiotic components (vegetation in not, indeed, included in the present study). Results of the study have been elaborated and the following Table 8.3 has been carried out.

As it can be observed from the analysis, it emerged that the cost for the disposal of an extensive green roof has only a slight incidence on its total life cycle cost. In addition, the analysis showed that the cost of the disposal of the substrate seems to be the main responsible for the disposal cost of the whole roof (85\%). The same conclusion can be drawn with respect to the initial capital cost, where the substrate resulted responsible for $44 \%$ of the total cost (Peri et al., 2012a, 2012b).

\subsubsection{A Contribution Towards a Simplified Economic Appraisal of the Feasibility of Green Roofs}

Obviously, when analysing an important building component, such as a green roof, economic aspects also need to be taken into consideration.

Results of a simple procedure to estimate the green roofs' economical effectiveness has also been briefly summarized here (see Fig. 8.4), based on a previous study conducted by the authors (Di Lorenzo et al., 2019), in which the evaluation of the periods of time in which a certain building requires an active cooling support in order to maintain the required indoor comfort conditions (estimated service time) has been transformed into the cost of the corresponding needed electric energy. Specifically, Fig. 8.4 comparatively shows the specific costs $\left(\mathrm{kWh} / \mathrm{m}^{3}\right)$ for the exante and the enhanced albedo scenarios of two Sicilian cities, Palermo and Messina.

The choice of an economic criterion concerning the running cost of the air conditioning system relies on the consideration that people usually decide to rent a building where to live based on the running cost of the HVAC systems.

As it can be observed, at least in the performed analysis in both cities, a higher reduction of the climatization costs has resulted when installing cool paints or cool membranes on the existing roofs rather than in case of adoption of green roofs. Despite some simplifying assumptions (some of them typically made in building 

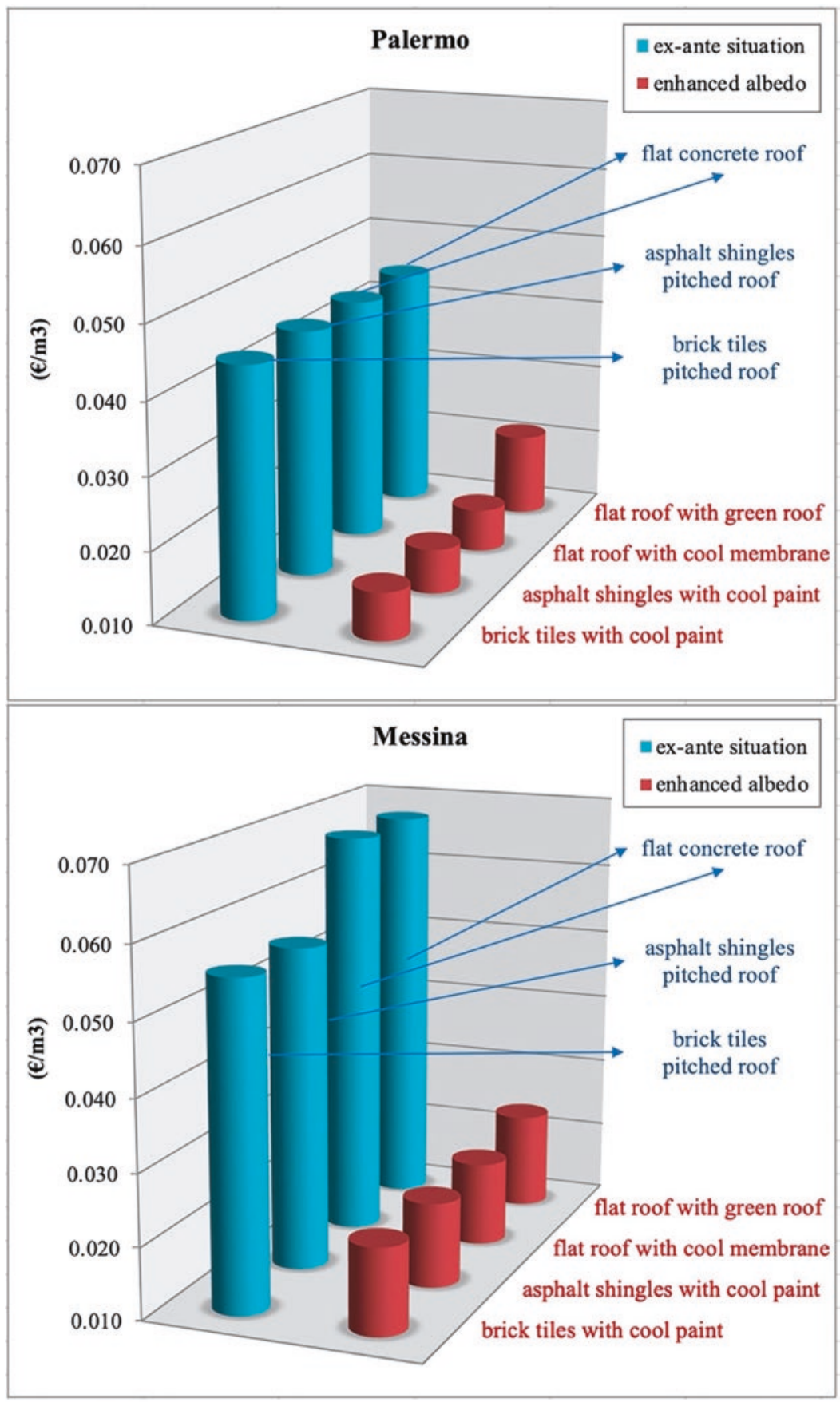

Fig. 8.4 Electric energy costs reduction of buildings with green roofs. (Adapted from Di Lorenzo et al., 2019) 
simulation) clearly affecting the results, this method can represent a preliminary and useful tool to support decision-makers when assessing the economic feasibility of these two technological alternatives.

\subsection{Conclusions}

This chapter deals with an increasingly important passive component of the building envelope, which is green roof. Some of the current gaps affecting the energy modelling, as well as the environmental and economic assessment of these building components have been presented. Contributions to their solution, which have arisen from both experimental and modelling research carried out by the authors, have been addressed in this chapter. Specifically, part of it provides a contribution in overcoming the current gaps related to the Life Cycle Costing (LCC) analyses phases, by taking into account the green roof disposal costs. In detail, it has arisen that the cost for the disposal of an extensive green roof has only a slight incidence on its total life cycle cost (4\%).

The lack of knowledge regarding the substrate in the application of the classical LCA methodology, as it has been demonstrated, also represents a critical aspect, which negatively affects green roofs' energy performance assessment. This issue has also been dealt with by reporting results of an LCA conducted on a green roof (whose greening type is extensive), where the analysis of a specific substrate was properly included by also considering the role of fertilizers used for the green roof maintenance. Specifically, it has been found that the substrate is the greatest contributor to some impact categories, such as Fresh Water Aquatic ecotoxicity (49\%), Eutrophication (59\%), and Acidification (46\%).

In addition, the absence of a proper database containing information (growth stage, leaf area index, and coverage ratio) relative to the parameters characterizing different green roof plant species, which technicians could use when a lack of field data occurs, has been pointed out. Besides, an estimation of the errors likely occurring when using not specific vegetation data for an energy estimation of a building equipped with a green roof, is presented; it has resulted that significant errors (up to $45 \%$ in the case of heating and up to $24 \%$ in the case of cooling) in the estimation of thermal loads might occur when using generic data for the vegetation parameters of an extensive green roof.

Finally, in order to provide a building's users (i.e., people occupying a given building, which are thus responsible for the energy bill) with an easy and yet effective tool for assessing the economic viability of green roofs, some observations regarding the economic appraisal of green roofs have been included as well.

In conclusion, based on considerations presented in this chapter, further analyses are highly recommended. In fact, there are still several research areas and technical difficulties that need to be addressed, as for instance the evaluation of the initial high construction and maintenance costs in sight of a proper economical evaluation (Mahdiyar et al., 2016; Tassicker, Rahnamanyiezekavat, \& Sutrisna, 2016), or the 
consideration of possible leakage occurrences (Baryła, Karczmarczyk, Brandyk, \& Bus, 2018).

Furthermore, another aspect that emerged from the research activity on green roofs carried out so far by the authors regards the importance of the availability of adequate simulation tools (La Gennusa et al., 2019a, 2019b; Mazzeo, Bevilacqua, De Simone, \& Arcuri, 2015), in order to facilitate both the design and assessment processes. Green roofs represent an increasingly important building passive component in urban contexts due to the many benefits that can be attributed to them. Green roofs allow indeed to reduce the air pollution.

\section{References}

Abhijith, K. V., Kumar, P., Gallagher, J., McNabola, A., Baldauf, R., Pilla, F., et al. (2017). Air pollution abatement performances of green infrastructure in open road and built-up street canyon environments - A review. Atmospheric Environment, 162, 71-86.

Baryła, A., Karczmarczyk, A., Brandyk, A., \& Bus, A. (2018). The influence of a green roof drainage layer on retention capacity and leakage quality. Water Science and Technology, 77(12), 2886-2895.

Bevilacqua, P., Bruno, R., \& Arcuri, N. (2020). Green roofs in a Mediterranean climate: Energy performances based on in-situ experimental data. Renewable Energy, 152, 1414-1430.

Bevilacqua, P., Mazzeo, D., Bruno, R., \& Arcuri, N. (2016). Experimental investigation of the thermal performances of an extensive green roof in the Mediterranean area. Energy and Buildings, $122,63-79$.

Bevilacqua, P., Mazzeo, D., Bruno, R., \& Arcuri, N. (2017). Surface temperature analysis of an extensive green roof for the mitigation of urban heat island in southern Mediterranean climate. Energy and Buildings, 150, 318-327.

Cirrincione, L., La Gennusa, M., Peri, G., Rizzo, G., Scaccianoce, G., Sorrentino, G., et al. (2020). Green roofs as effective tools for improving the indoor comfort levels of buildings - An application to a case study in Sicily. Applied Sciences, 10(3), 893.

De Pury, D. G. G., \& Farquhar, G. D. (1997). Simple scaling of photosynthesis from leaves to canopies without the errors of big-leaf models. Plant, Cell \& Environment, 20, 537-557.

Del Barrio, E. P. (1998). Analysis of the green roofs cooling potential in buildings. Energy and Buildings, 27, 179-193.

Di Lorenzo, D., Casto, B. M. L., Peri, G., Rizzo, G., Scaccianoce, G., \& Tambani, C. (2019). Enhancing values of roofs albedo for lowering cities' air temperature and electric demand of buildings: A simple economic evaluation. IOP Conference Series: Materials Science and Engineering, 609(7).

EnergyPlus. https://energyplus.net. Accessed 10 June 2020.

Feng, C., Meng, Q., \& Zhang, Y. (2010). Theoretical and experimental analysis of the energy balance of extensive green roofs. Energy and Buildings, 42, 959-965.

Ferrante, P., La Gennusa, M., Peri, G., Rizzo, G., \& Scaccianoce, G. (2016). Vegetation growth parameters and leaf temperature: Experimental results from a six plots green roofs' system. Energy, 115, 1723-1732.

Francis, L., \& Jensen, M. (2017). Benefits of green roofs: A systematic review of the evidence for three ecosystem services. Urban Forestry \& Urban Greening, 28, 167-176.

Jaffal, I., Ouldboukhitine, S. E., \& Belarbi, R. (2012). A comprehensive study of the impact of green roofs on building energy performance. Renewable Energy, 43, 157-164. 
Köhler, M., \& Ksiazek-Mikenas, K. (2018). Green roofs as habitats for biodiversity. In G. Pérez \& K. Perini (Eds.), Nature based strategies for urban and building sustainability (pp. 239-249). Oxford, UK: Butterworth-Heinemann.

Kosareo, L., \& Ries, R. (2007). Comparative environmental life cycle assessment of green roofs. Building and Environment, 42, 2606-2613.

Koura, J., Manneh, R., Belarbi, R., El Khoury, V., \& El Bachawati, M. (2017). Seasonal variability of temperature profiles of vegetative and traditional gravel-ballasted roofs: A case study for Lebanon. Energy and Buildings, 151, 358-364.

La Gennusa, M., Marino, C., Nucara, A., Peri, G., Rizzo, G., \& Scaccianoce, G. (2019a). Green roof and thermal insulation of buildings: Analysis of the actual effectiveness and achievable benefit. In V. Corrado \& A. Gasparella (Eds.), Proceedings of building simulation 2019: 16th conference of IBPSA Roma, 2-4 Settembre 2019 (pp. 5006-5013).

La Gennusa, M., Marino, C., Nucara, A., Peri, G., Rizzo, G., \& Scaccianoce, G. (2019b). Green vs traditional roofs: Assessing their actual benefits through an integrated Indicator developed for cool roofs. In V. Corrado \& A. Gasparella (Eds.), Proceedings of building simulation 2019: 16th conference of IBPSA Roma, 2-4 Settembre 2019 (pp. 5014-5021).

La Gennusa, M., Peri, G., Scaccianoce, G., Sorrentino, G., \& Aprile S. (2018). A case-study of green roof monitoring: The building of Council for Agricultural Research and Economics in Bagheria, (Italy). In 2018 IEEE international conference on environment and electrical engineering and 2018 IEEE industrial and commercial power systems, Europe.

Liu, C., \& Hornikx, M. (2018). Effect of water content on noise attenuation over vegetated roofs: Results from two field studies. Building and Environment, 146, 1-11.

Mahdiyar, A., Tabatabaee, S., Sadeghifam, A. N., Mohandes, S. R., Abdullah, A., \& Meynagh, M. M. (2016). Probabilistic private cost-benefit analysis for green roof installation: A Monte Carlo simulation approach. Urban Forestry and Urban Greening, 20, 317-327.

Mazzeo, D., Bevilacqua, P., De Simone, M., \& Arcuri, N. (2015). A new simulation tool for the evaluation of energy performances of green roofs. In Proceedings of BSA 2015. https://doi. org/10.13140/2.1.5099.6008.

Monteith, J. L. (1965). Evaporation and the environment. In G. E. Fogg (Ed.), The state and movement of water in living organisms (Symposia of the Society for Experimental Biology Series 19) (pp. 205-234). New York: Springer.

Niachou, A., Papakonstantinou, M., Santamouris, M., Tsangrassoulis, A., \& Mihalakakou, G. (2001). Analysis of the green roof thermal properties and investigation of its energy performance. Energy and Buildings, 33, 719-729.

Peri, G., Rizzo, G., Scaccianoce, G., La Gennusa, M., \& Jones, P. (2016). Vegetation and soil Related parameters for computing solar radiation exchanges within green roofs: Are the available values adequate for an easy modeling of their thermal behavior? Energy and Buildings, $129,535-548$.

Peri, G., Rizzo, G., Scaccianoce, G., \& Sorrentino, G. (2013). Role of green coverings in mitigating heat island effects: An analysis of physical models. Applied Mechanics and Materials, 261-262, 251-256.

Peri, G., Traverso, M., Finkbeiner, M., \& Rizzo, G. (2012a). Embedding "substrate" in environmental assessment of green roofs life cycle: Evidences from an application to the whole chain in a Mediterranean site. Journal of Cleaner Production, 35, 274-287.

Peri, G., Traverso, M., Finkbeiner, M., \& Rizzo, G. (2012b). The cost of green roofs disposal in a life cycle perspective: Covering the gap. Energy, 48, 406-414.

Quezada-García, S., Espinosa-Paredes, G., Polo-Labarrios, M. A., Espinosa-Martínez, E. G., \& Escobedo-Izquierdo, M. A. (2020). Green roof heat and mass transfer mathematical models: A review. Building and Environment, 170, 106634.

Saadatian, O., Sopian, K., Salleh, E., Lim, C. H., Riffat, S., Saadatian, E., et al. (2013). A review of energy aspects of green roofs. Renewable and Sustainable Energy Reviews, 23, 155-168.

Sailor, D. J. (2008). A green roof model for building energy simulation programs. Energy and Buildings, 40, 1466-1478. 
Sailor, D. J., \& Hagos, M. (2011). An updated and expanded set of thermal property data for green roof growing media. Energy and Buildings, 43, 2298-2303.

Saiz, S., Kennedy, C., Bass, B., \& Snail, K. (2006). Comparative life cycle assessment of standard and green roofs. Environmental Science \& Technology, 40, 4312-4316.

Santamouris, M. (2014). Cooling the cities - A review of reflective and green roof mitigation technologies to fight heat island and improve comfort in urban environments. Solar Energy, 103, 682-703.

Santamouris, M., Pavlou, C., Doukas, P., Mihalakakou, G., Synnefa, A., Hatzibiros, A., et al. (2007). Investigating and analysing the energy and environmental performance of an experimental green roof system installed in a nursery school building in Athens, Greece. Energy, 32(9), 1781-1788.

Shafique, M., Azam, A., Rafiq, M., Ateeq, M., \& Luo, X. (2020). An overview of life cycle assessment of green roofs. Journal of Cleaner Production, 250, 119471.

Shafique, M., Kim, R., \& Rafiq, M. (2018). Green roof benefits, opportunities and challenges - A review. Renewable and Sustainable Energy Reviews, 90, 757-773.

Silva, C., Gomes, M. G., \& Silva, M. (2016). Green roofs energy performance in Mediterranean climate. Energy and Buildings, 116, 318-325.

Solcerova, A., van de Ven, F., Wang, M., Rijsdijk, M., \& van de Giesen, N. (2017). Do green roofs cool the air? Building and Environment, 111, 249-255.

Soulis, K. X., Ntoulas, N., Nektarios, P. A., \& Kargas, G. (2017). Runoff reduction from extensive green roofs having different substrate depth and plant cover. Ecological Engineering, $102,80-89$.

Tassicker, N., Rahnamanyiezekavat, P., \& Sutrisna, M. (2016). An insight into the commercial viability of green roofs in Australia. Sustainability, 8(7), 603.

Ulubeyli, S., Arslan, V., \& Kazaz, A. (2017). Comparative life cycle costing analysis of green roofs: The regional aspect. Periodicals of Engineering and Natural Sciences, 5(2), 136-144.

Van Renterghem, T. (2018). Green roofs for acoustic insulation and noise reduction. In G. Pérez \& K. Perini (Eds.), Nature based strategies for urban and building sustainability (pp. 167-179). Oxford, UK: Butterworth-Heinemann.

Vijayaraghavan, K., Reddy, D. H. K., \& Yun, Y. S. (2019). Improving the quality of runoff from green roofs through synergistic biosorption and phytoremediation techniques: A review. Sustainable Cities and Society, 46, 101381.

Walter, C. A., Burnham, M. B., Gilliam, F. S., \& Peterjohn, W. T. (2015). A reference-based approach for estimating leaf area and cover in the forest herbaceous layer. Environmental Monitoring and Assessment, 187, 657-666.

Woodward, D. G. (1997). Life cycle costing-theory, information acquisition and application. International Journal of Project Management, 15(6), 335-344.

Yang, J., llamathy, D., Kumar, M., Pyrgou, A., Chong, A., Santamouris, M., et al. (2018). Green and cool roofs' urban heat island mitigation potential in tropical climate. Solar Energy, 173, 597-609.

Zhang, Q., Miao, L., Wang, X., Liu, D., Zhu, L., Zhou, B., et al. (2015). The capacity of greening roof to reduce stormwater runoff and pollution. Landscape and Urban Planning, 144, $142-150$.

Zhao, M., Tabares-Velasco, P. C., Srebric, J., Komarneni, S., \& Berghage, R. (2014). Effects of plant and substrate selection on thermal performance of green roofs during the summer. Building and Environment, 78, 199-211.

Zinzi, M., \& Agnoli, S. (2012). Cool and green roofs. An energy and comfort comparison between passive cooling and mitigation urban heat island techniques for residential buildings in the Mediterranean region. Energy and Buildings, 55, 66-76. 
Open Access This chapter is licensed under the terms of the Creative Commons Attribution 4.0 International License (http://creativecommons.org/licenses/by/4.0/), which permits use, sharing, adaptation, distribution and reproduction in any medium or format, as long as you give appropriate credit to the original author(s) and the source, provide a link to the Creative Commons license and indicate if changes were made.

The images or other third party material in this chapter are included in the chapter's Creative Commons license, unless indicated otherwise in a credit line to the material. If material is not included in the chapter's Creative Commons license and your intended use is not permitted by statutory regulation or exceeds the permitted use, you will need to obtain permission directly from the copyright holder. 